\title{
Missbrauch im Europäischen Zivilverfahrensrecht
}

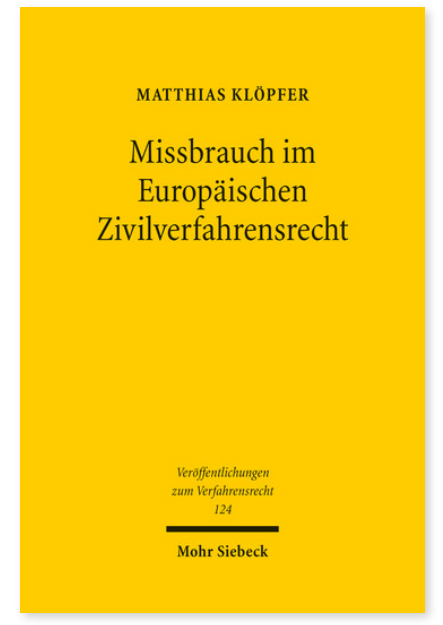

2016. XXV, 432 Seiten. VVerfR 124

ISBN 978-3-16-154593-1

DOI 10.1628/978-3-16-154593-1

eBook PDF 79,00€

ISBN 978-3-16-154255-8

fadengeheftete Broschur 79,00€
Das Europäische Zivilverfahrensrecht erscheint gelegentlich als Materie, die Rechtsmissbrauch und Umgehungsstrategien geradezu begünstigt. Die Zurückhaltung der Gerichte und der Rechtswissenschaft, einer zweckwidrigen oder arglistigen Inanspruchnahme von Verfahrensrecht Einhalt zu gebieten, wird mit den Eigenheiten des Rechtsgebiets selbst begründet. In nicht näher definierten Ausnahmefällen spricht man sich dennoch für einen Vorrang der Einzelfallgerechtigkeit aus, wobei der dogmatische Ansatzpunkt hierfür in aller Regel ungenannt bleibt. Vor diesem Hintergrund untersucht Matthias Klöpfer, ob und in welchen Grenzen mittels des sogenannten unionsrechtlichen Missbrauchsverbots die missbräuchliche Inanspruchnahme von Vorschriften des Europäischen Zivilverfahrensrechts reguliert werden kann. Dabei stützt er sich auf rechtsvergleichende Erkenntnisse im Mehrebenensystem des Unionsrechts, die Wirkungsweise und den Geltungsanspruch allgemeiner Rechtsgrundsätze und die Lehren der Interessenjurisprudenz.

Matthias Klöpfer Geboren 1985; Studium der Rechtswissenschaft in Konstanz; wiss. Mitarbeiter am Lehrstuhl für Bürgerliches Recht, Zivilprozessrecht, Internationales Privatrecht und Rechtsvergleichung der Universität Konstanz.
Jetzt bestellen:

https://mohrsiebeck.com/buch/missbrauch-im-europaeischen-zivilverfahrensrecht-9783161545931?no_cache=1 order@mohrsiebeck.com

Telefon: +49 (0)7071-923-17

Telefax: $+49(0) 7071-51104$ 